\title{
Experience with women having uterine cancer in Eastern India: a hospital based study
}

\author{
Priyanka Singh ${ }^{1}$, Chandrima Ray ${ }^{1}$, Ranajit Mandal ${ }^{2 *}$
}

\begin{abstract}
${ }^{1}$ Department of Gynecological Oncology, Super Speciality Cancer Institute and Hospital, Lucknow, Uttar Pradesh, India

${ }^{2}$ Department of Gynecological Oncology, Chittaranjan National Cancer Institute, Kolkata, West Bengal, India
\end{abstract}

Received: 24 June 2020

Accepted: 30 June 2020

\author{
*Correspondence: \\ Dr. Ranajit Mandal, \\ E-mail: kranajitmandal@yahoo.com
}

Copyright: () the author(s), publisher and licensee Medip Academy. This is an open-access article distributed under the terms of the Creative Commons Attribution Non-Commercial License, which permits unrestricted non-commercial use, distribution, and reproduction in any medium, provided the original work is properly cited.

\begin{abstract}
Background: The changing lifestyle has led to a rise in obesity, diabetes and hypertension in India which the most important risk factors for developing uterine cancer. The treatment of uterine cancer is evolving and requires proper evaluation and often adjuvant treatment for better survival. The disease being associated with symptoms of abnormal uterine bleeding often ends up being inadequately managed by non-oncologists practicing in a generalist setting in India. The current study was aimed to audit and observe any difference in outcome of patients primarily treated in the oncology set-up of the Chittaranjan National Cancer Institute, which is a regional cancer center in India versus those receiving primary treatment in a non-oncological set-up.

Methods: Retrospective data was collected from hospital records after setting inclusion and exclusion criteria for the study.

Results: There is poor correlation between the endometrial biopsy and histopathology findings of patients operated in non-oncological setting as compared to that in the institute. The overall survival of patients operated in the institute was superior to those treated outside.

Conclusions: Patients having risk factors and symptoms akin to that of uterine carcinoma must be treated in an oncological set-up ideally.
\end{abstract}

Keywords: Endometrial carcinoma, Gynecologic oncology, Hysterectomy

\section{INTRODUCTION}

Endometrial cancer is a lifestyle related cancer with a higher incidence in the high-income countries as compared to India. ${ }^{1,2}$ It is among the ten leading cancer sites among seven out of twelve PBCRs in India. ${ }^{3}$ There has been a recent shift in the lifestyles of Indian urban population across the country leading to an increase in incidence of obesity and diabetes, which are both known risk factors for genesis of uterine cancer. ${ }^{4}$ Postmenopausal bleeding is the most common presentation of this malignancy. ${ }^{5}$ The present retrospective study describes the demographics, risk association, treatment and survival of patients presenting with uterine cancer at
Chittaranjan National Cancer Institute, Kolkata between 2011 to 2018.

\section{METHODS}

An audit framework was designed to study the outcome in terms of survival of patients with uterine cancer presenting at the institute between years 2011 to 2018 . Inclusion criteria was patients who had been histologically diagnosed as malignant and undergone complete treatment and follow-up at the institute, those who had registered but whose diagnosis could not be confirmed as malignant or had not undergone complete treatment and/or follow-up at the institute were excluded 
from the study. Therefore, the total number of participants eligible for the study was 60 .

The patients' records were searched for confirmation of diagnosis and staging, mode of primary and adjuvant treatment as per the patient's stage and follow-up on a regular basis. The data of such patients was collected using Microsoft Excel datasheets and the analysis of data was done using IBM SPSS statistics version 20. The endpoint of the study was overall survival. The study group was analyzed by two major groups based on age $\leq 45$ and $>45$ years and has undergone primary treatment in the institute or outside (non-oncological set-up).

\section{Statistical analysis}

Over-all survival was calculated using the Kaplan Meier method where death was an event and those who could not be contacted were censored for the sake of the study. Agreement between preoperative endometrial biopsy and post-operative specimen histopathology was done using kappa statistics. ${ }^{6}$ All analysis was done using SPSS version 20.

\section{RESULTS}

Total number of patients registered with a diagnosis of uterine/endometrial cancer was one hundred and six, out of which thirty-six patients did not undergo any further assessment or treatment at the institute and ten patients had no follow-up at the institute. The remaining sixty patients were included in the study. The medical records of the patients included in the study were reviewed and data was collected under various heads.

Among the cases being studied majority were above 45 years of age with three patients having history of cancer of some site, in the family. Eighty percent of the patients were literate and around fifty-seven percent of the cases had a parity of more than one (Table 1). Around forty seven percent patients had co-morbidities amongst which the commonest was diabetes mellitus, while fifteen percent patients had a combination of diabetes and hypertension (Table 2).

Table 1: Patient characteristics with regard to age, literacy, parity, comorbidities and family history of cancer.

\begin{tabular}{|c|c|c|}
\hline Characteristics & Number & $\%$ \\
\hline Total cases & 60 & \\
\hline Age years $\leq 45$ & 14 & $23.3 \%$ \\
\hline$>45$ & 46 & $76.7 \%$ \\
\hline \multicolumn{3}{|l|}{ Family history of cancer } \\
\hline Nil & 57 & \\
\hline Yes & 3 & \\
\hline \multicolumn{3}{|l|}{ Literacy } \\
\hline & 48 & $80.0 \%$ \\
\hline & 12 & $20.0 \%$ \\
\hline \multicolumn{3}{|l|}{ Parity } \\
\hline Parity less than /equal to 1 & 26 & $43.3 \%$ \\
\hline Parity more than one & 34 & $56.7 \%$ \\
\hline
\end{tabular}

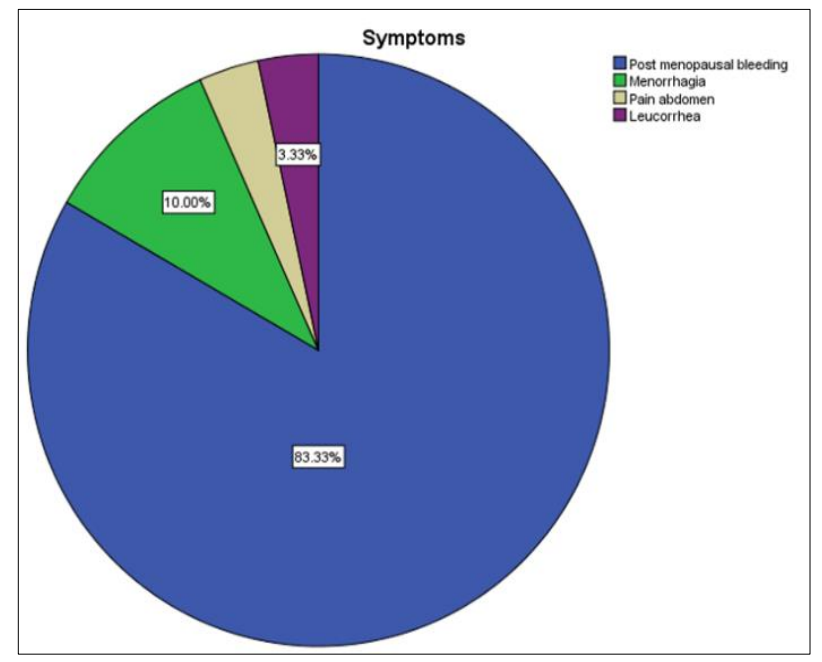

Figure 1: Distribution of symptoms among the patients.

Table 2: Frequency of various co-morbidities among the patients.

\begin{tabular}{|lllll|}
\hline Co-morbidities & Frequency & Percentage & Valid percentage & Cumulative percentage \\
\hline Diabetes mellitus & 10 & $16.7 \%$ & 16.7 & $16.7 \%$ \\
\hline Hypertension & 6 & $10.0 \%$ & 10.0 & $26.7 \%$ \\
\hline Hypothyroid & 1 & $1.7 \%$ & 1.7 & $28.3 \%$ \\
\hline Diabetes mellitus + hypertension & 8 & $13.3 \%$ & 13.3 & $41.7 \%$ \\
\hline $\begin{array}{l}\text { Diabetes+hypertension+ischemic heart } \\
\text { disease }\end{array}$ & 1 & $1.7 \%$ & 1.7 & $43.3 \%$ \\
\hline Diabetes+hypertension+COPD & 1 & $1.7 \%$ & 1.7 & $45.0 \%$ \\
\hline CNS & 1 & $1.7 \%$ & 1.7 & $46.7 \%$ \\
\hline No co-morbidity & 32 & $53.3 \%$ & 53.3 & $100.0 \%$ \\
\hline Total & 60 & $100.0 \%$ & 100.0 & \\
\hline
\end{tabular}


Table 3: Symptom-wise distribution of various histopathology diagnosis.

\begin{tabular}{|c|c|c|c|c|c|c|c|c|}
\hline \multicolumn{2}{|c|}{ Symptoms* histopathology at biopsy crosstabulation } & & & & & & & \\
\hline & & \multicolumn{6}{|c|}{ Histopathology at biopsy } & \multirow[b]{2}{*}{ Total } \\
\hline & & 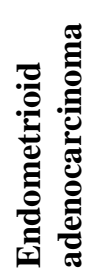 & 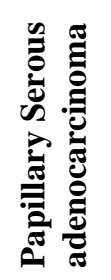 & 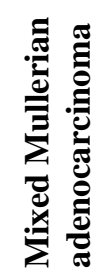 & 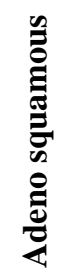 & 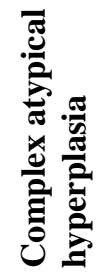 & 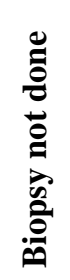 & \\
\hline \multirow{4}{*}{ Symptoms } & Post-menopausal bleeding & 37 & 6 & 1 & 0 & 3 & 3 & 50 \\
\hline & Menorrhagia & 4 & 0 & 0 & 1 & 0 & 1 & 6 \\
\hline & Pain abdomen & 2 & 0 & 0 & 0 & 0 & 0 & 2 \\
\hline & Leucorrhoea & 2 & 0 & 0 & 0 & 0 & 0 & 2 \\
\hline \multicolumn{2}{|l|}{ Total } & 45 & 6 & 1 & 1 & 3 & 4 & 60 \\
\hline
\end{tabular}

Table 4: Cross-tabulation of histopathology diagnosis before and after surgery.

\begin{tabular}{|c|c|c|c|c|c|c|c|}
\hline \multicolumn{8}{|c|}{ Histopathology at biopsy *histopathology at surgery crosstabulation } \\
\hline & & \multicolumn{5}{|c|}{ Histopathology at surgery } & \multirow[b]{2}{*}{ Total } \\
\hline & & 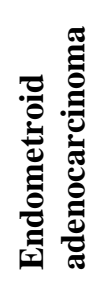 & 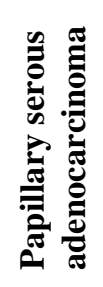 & 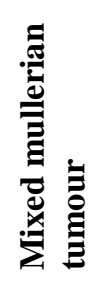 & 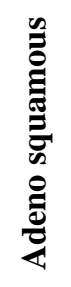 & 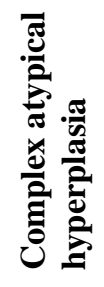 & \\
\hline \multirow{6}{*}{$\begin{array}{l}\text { Histopathology } \\
\text { at biopsy }\end{array}$} & Endometrioid adenocarcinoma & 41 & 1 & 2 & 0 & 1 & 45 \\
\hline & Papillary serous adenocarcinoma & 0 & 5 & 1 & 0 & 0 & 6 \\
\hline & Mixed mullerian adenocarcinoma & 0 & 0 & 1 & 0 & 0 & 1 \\
\hline & Aden squamous & 0 & 0 & 0 & 1 & 0 & 1 \\
\hline & Complex atypical hyperplasia & 3 & 0 & 0 & 0 & 0 & 3 \\
\hline & Biopsy not done & 4 & 0 & 0 & 0 & 0 & 4 \\
\hline \multicolumn{2}{|l|}{ Total } & 48 & 6 & 4 & 1 & 1 & 60 \\
\hline
\end{tabular}

Table 5: Correlation between pre hysterectomy and post hysterectomy biopsy diagnosis of those operated in oncologic set-up versus those operated outside.

\section{Symmetric measures}

\begin{tabular}{|c|c|c|c|c|c|c|}
\hline \multicolumn{3}{|c|}{ Hysterectomy done in non- oncology set-up } & \multirow{2}{*}{$\begin{array}{c}\text { Value } \\
0.222\end{array}$} & \multirow{2}{*}{$\begin{array}{l}\text { Asymp. } \\
\text { Std. Error } \\
0.184\end{array}$} & \multirow{2}{*}{$\begin{array}{l}\begin{array}{l}\text { Approx. } \\
\mathbf{T}^{\mathbf{b}}\end{array} \\
3.326 \\
\end{array}$} & \multirow{2}{*}{$\begin{array}{l}\text { Approx. } \\
\text { Sig. } \\
0.001\end{array}$} \\
\hline Yec & Measure of agreement & Kappa & & & & \\
\hline Yes & Number of valid cases & & 28 & & & \\
\hline \multirow{2}{*}{ No } & Measure of agreement & Kappa & 0.604 & 0.134 & 5.234 & 0.000 \\
\hline & Number of valid cases & & 31 & & & \\
\hline \multirow{2}{*}{ Total } & Measure of agreement & Kappa & 0.483 & 0.119 & 6.149 & 0.000 \\
\hline & Number of valid cases & & 59 & & & \\
\hline
\end{tabular}

The most common symptom of patients presenting to the hospital was post-menopausal bleeding (83.3\%), followed by menorrhagia (10\%) (Figure 1). Among the postmenopausal patients the most common histopathology was endometroid adenocarcinoma. Postmenopausal bleeding was also the commonest symptom for other histopathology types like, papillary serous adenocarcinoma and mixed mullerian tumour (Table 3 ).

Since the patients registered in the institute, some of them had already undergone primary treatment outside, the agreement between preoperative endometrial biopsy and 
post-operative histopathology was seen using kappa statistics and it was found that there was poor agreement between the pre-operative and post-operative histopathology reports of those operated outside as compared to those operated in the institute (Table 4 and $5)$.

Table 6: Cross-tabulation showing age-wise distribution of patients in various stages.

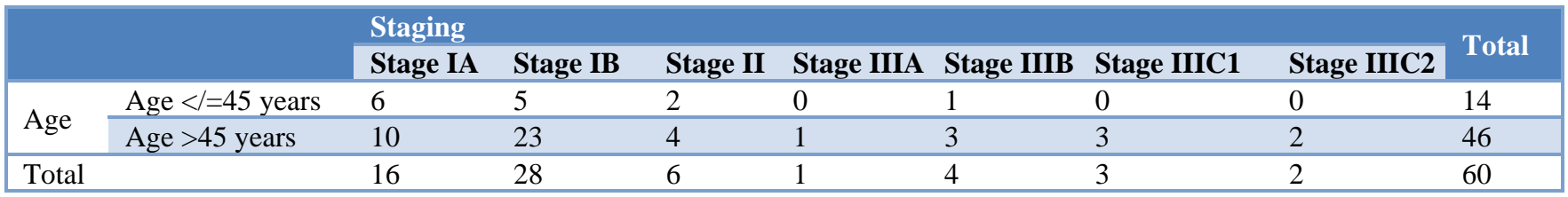

Table 7: Mean survival in two groups compared in months.

\begin{tabular}{|c|c|c|c|c|c|c|c|c|}
\hline \multirow{3}{*}{$\begin{array}{l}\text { Hysterectomy at } \\
\text { presentation }\end{array}$} & \multicolumn{4}{|l|}{ Mean ${ }^{a}$} & \multicolumn{4}{|l|}{ Median } \\
\hline & \multirow{2}{*}{ Estimate } & \multirow{2}{*}{$\begin{array}{l}\text { Std. } \\
\text { error }\end{array}$} & \multicolumn{2}{|c|}{$\begin{array}{l}95 \% \text { confidence } \\
\text { interval }\end{array}$} & \multirow{2}{*}{ Estimate } & \multirow{2}{*}{$\begin{array}{l}\text { Std. } \\
\text { error }\end{array}$} & \multicolumn{2}{|c|}{$\begin{array}{l}95 \% \text { confidence } \\
\text { interval }\end{array}$} \\
\hline & & & $\begin{array}{l}\text { Lower } \\
\text { bound }\end{array}$ & $\begin{array}{l}\text { Upper } \\
\text { bound }\end{array}$ & & & $\begin{array}{l}\text { Lower } \\
\text { bound }\end{array}$ & $\begin{array}{l}\text { Upper } \\
\text { bound }\end{array}$ \\
\hline Yes & 75.597 & 5.867 & 64.098 & 87.095 & . & . & . & . \\
\hline No & 105.917 & 7.211 & 91.784 & 120.050 & . & . & . & . \\
\hline Overall & 98.410 & 6.856 & 84.973 & 111.847 & . & . & . & . \\
\hline
\end{tabular}

a. Estimation is limited to the largest survival time if it is censored.

Table 8: Equality of survival distributions in the two survival curves with censoring.

\begin{tabular}{|llll|}
\hline \multicolumn{2}{|c|}{ Overall comparisons } & & \\
\hline & Chi-square & df & Sig. \\
\hline $\begin{array}{l}\text { Log rank } \\
\text { (mantel-cox) }\end{array}$ & 2.786 & 1 & 0.095 \\
\hline
\end{tabular}

Test of equality of survival distributions for the different levels of hysterectomy at presentation.

Table 9: Loss to follow-up.

\begin{tabular}{|llll|}
\hline Sr. No. & $\begin{array}{l}\text { Patient } \\
\text { operated } \\
\text { outside }\end{array}$ & $\begin{array}{l}\text { Patient } \\
\text { operated at } \\
\text { Institute }\end{array}$ & $\begin{array}{l}\text { Total lost } \\
\text { to follow- } \\
\text { up }\end{array}$ \\
\hline $\begin{array}{l}\text { Lost to } \\
\text { follow-up }\end{array}$ & 4 & 2 & 6 \\
\hline
\end{tabular}

The majority of patients presented in stage $1 \mathrm{~b}$ followed by stage $1 \mathrm{a}$, that is early stage cancer (Table 6). The survival of patients was analysed based on primary treatment (hysterectomy) done outside (non-oncology set-up) as compared to those treated at the institute. The survival was superior for those treated in the institute (Figure 2). The mean survival time was 105.92 months for those operated in the institute as compared to 75.6 months for those operated outside (Table 7). The equality of survival in the two populations (operated in the institute and outside) with censoring was compared using log rank test and the difference was 0.095 (Table 8).

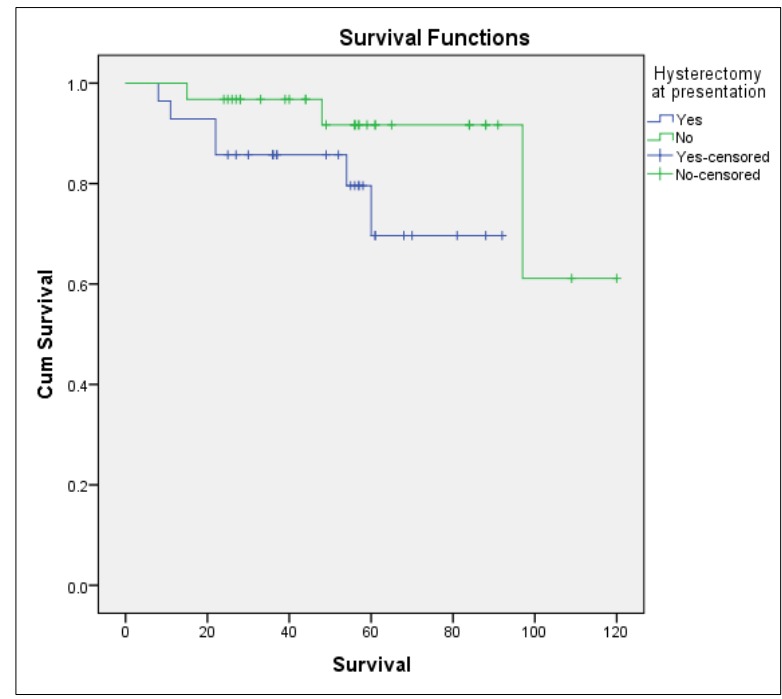

Figure 2: Kaplan Meier curve comparing survival of those having primary surgery outside as compared to those operated in the institute.

There were six losses to follow-up and most of those patients were from the group that had undergone primary treatment outside in a non-oncological set-up (Table 9).

\section{DISCUSSION}

Incidental diagnosis of endometrial cancer following hysterectomy poses a clinical dilemma to the gynecologic 
oncologist. Incompletely staged women with endometrial carcinoma need to be further investigated for deciding on mode of adjuvant therapy, if required. The present study aims to highlight the importance of complete surgical staging in the adequate and appropriate management of endometrial cancer, especially in early stage endometrial cancer, by specialized gynecologic oncology units for better outcome of such patients.

In this study, majority of the women were above 45 years of age. The most common presenting symptom was postmenopausal bleeding. Among the postmenopausal patients the most common histopathology was endometroid adenocarcinoma. Most of the patients were diagnosed with early stage endometrial carcinoma (stage $1 \mathrm{a}$ and $\mathrm{b})$.

The recommended management of women with postmenopausal bleeding is radiological assessment of the uterus and adnexa with measurement of endometrial thickness followed by endometrial aspiration or biopsy in case of thickened endometrium $>4 \mathrm{~mm}^{7}$ A diagnosed case of endometrial cancer should undergo complete surgical staging including assessment of the peritoneal cavity and retroperitoneal lymph node status. ${ }^{8}$ However, many such symptomatic postmenopausal women are inadequately investigated and then undergo inadequate surgery, following which they are referred to higher cancer centers for further management. ${ }^{9}$ As inferenced from this study, such women have poorer survival (Figure 2).

With better oncological facilities, tissue specimens of endometrial cancer cases should be examined by oncopathologists as those not adept at diagnosing malignancy may be inaccurate at diagnosis, as what was observed in this study where correlation between pre-hysterectomy histopathology (outside the study institute) and post hysterectomy histopathology (at the study institute) was poor (Table 5 kappa 0.4).

Patients of all malignancies in general and those with endometrial cancer in particular require regular follow up to detect early recurrence or disease progression, if any. Authors observed from this study that patients who were operated at this study center have a tendency of continuing follow up better than those operated outside (Table 9).

Most of the patients find it difficult to reconcile to resurgery as was observed in this study where none of the patients operated outside consented to undergoing surgical restaging. The survival of patients was not adversely affected by not undergoing surgical restaging.

Most of the patients who required adjuvant therapy based on their radiological and histopathological findings had good survival. ${ }^{9}$ Subjecting patients to re-surgery just to adequately stage the disease, is an added risk to such patients who are suspected to have endometrial cancer, especially in a low-middle income country when the cost to treatment is increased as most of the treatment is borne by out of pocket expenditure. ${ }^{10}$

It was finally observed that patients who were primarily operated in specialized gynecologic oncology setup had a superior survival as compared to patients in a nononcology setup. Currently, there are no studies in the literature for endometrial cancer, however, a study by Engelen MJ et al, describes a superior survival in ovarian cancer patients treated primarily by a gynecological oncologist. $^{11}$

\section{CONCLUSION}

Patients with post-menopausal bleeding must always undergo an endometrial evaluation by biopsy before undergoing a hysterectomy, as the overall survival is better if women diagnosed as endometrial cancer are operated in an oncological set-up than in a general gynecological set-up.

\section{ACKNOWLEDGMENTS}

Authors would like to thank Dr. D. Banerjee, Chittaranjan National Cancer Institute for the encouragement to carry out the work.

\section{Funding: No funding sources}

Conflict of interest: None declared

Ethical approval: The study was approved by the Institutional Ethics Committee

\section{REFERENCES}

1. Setiawan VW, Yang HP, Pike MC, McCann SE, Yu $\mathrm{H}$, Xiang YB, et al. Type I and II endometrial cancers: have they different risk factors? J Clin Oncol. 2013;31(20):2607-18.

2. Bray F, Ferlay J, Soerjomataram I, Siegel RL, Torre LA, Jemal A. Global cancer statistics 2018: GLOBOCAN estimates of incidence and mortality worldwide for 36 cancers in 185 countries. CA Cancer J Clin. 2018;68(6):394-424.

3. Atlas of cancer registry in India; national cancer registry programme, chapter 3-5. Available at: http://www.ncdirindia.org/ncrp/ca/chapter3_5.aspx. Accessed on $6^{\text {th }}$ May 2020.

4. Ahirwar R, Mondal PR. Prevalence of obesity in India: a systematic review. Diabetes Metab Syndr. 2019;13(1):318-21.

5. Hacker NF, Friedlander ML. Chapter 9, Uterine cancer. In: Berek and Hacker's Gynecologic Oncology. $6^{\text {th }}$ Ed Wolters Kluwer; 2015:390-442.

6. Interrater reliability: the kappa statistic Mary L. McHugh Biochem Med (Zagreb) 2012;22(3):276-82.

7. RCOG Green-Top guideline No. 67. Available at: https://www.rcog.org.uk. Accessed on $1^{\text {st }}$ June 2020. 
8. NCCN Guideline on Uterine Neoplasm version 1. 2020. Available at: www.nccn.org. Accessed on $1^{\text {st }}$ 2020.

9. Thomas V, Thomas A, Sebastian A, Chandy R, Peedicayil A. Inadequately staged endometrial cancer: a clinical dilemma. Indian J Surg Oncol. 2018;9(2):166-70.

10. Pandey A, Ploubidis GB, Clarkec L, Dandonaa L. Trends in catastrophic health expenditure in India: 1993 to 2014. Bulletin WHO. 2018;96:18-28.

11. Engelen MJ, Kos HE, Willemse PH, Aalders JG, de Vries EG, Schaapveld M, et al. Surgery by consultant gynecologic oncologists improves survival in patients with ovarian carcinoma. Cancer. 2006;106(3):589-98.

Cite this article as: Singh $\mathrm{P}$, Ray $\mathrm{C}$, Mandal R.

Experience with women having uterine cancer in Eastern India: a hospital based study. Int J Reprod Contracept Obstet Gynecol 2020;9:3165-70. 